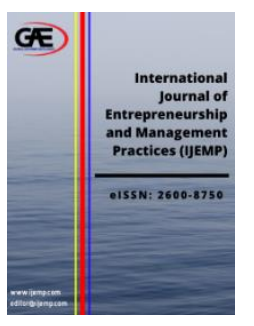

\author{
INTERNATIONAL JOURNAL OF \\ ENTREPRENEURSHIP AND \\ MANAGEMENT PRACTICES \\ (IJEMP) \\ www.ijemp.com
}

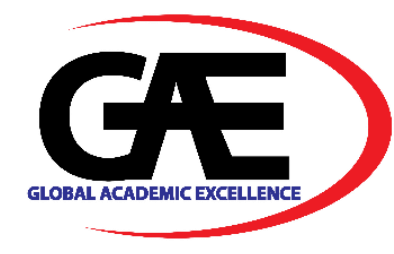

\title{
SUSTAINING THE GROWTH OF RURAL SMES: EFFECT OF FINANCIAL ACCESS AND ENTREPRENEURIAL CHARACTERISTICS ON BUSINESS PERFORMANCE IN A FELDA SCHEME IN PAHANG
}

\author{
Shuhaimi Mohd Sauh ${ }^{1 *}$, Moha Asri Abdullah², Rozailin Abdul Rahman ${ }^{3}$ \\ 1 School of Management and Business, Manipal International University, Nilai, Negeri Sembilan, Malaysia \\ Email: shuhaimi.mohd@miu.edu.my \\ 2 Kulliyah of Economics and Management Sciences, International Islamic University Malaysia, Malaysia \\ Email: mosri@iium.edu.my \\ 3 Kulliyah of Economics and Management Sciences, International Islamic University Malaysia, Malaysia \\ Email: rozailin@iium.edu.my \\ Corresponding Author
}

\section{Article Info:}

Article history:

Received date: 31.01 .2021

Revised date: 15.02 .2021

Accepted date: 18.03 .2021

Published date: 25.03.2021

\section{To cite this document:}

Sauh, S. M., Abdullah, M. A., \& Rahman, R. A. (2021). Sustaining the Growth of Rural SMEs: Effect of Financial Access and Entrepreneurial Characteristics on Business Performance in A Felda Scheme in Pahang. International Journal of Entrepreneurship and Management Practices, 4 (13), 89-108.

\begin{abstract}
:
In Malaysia, Small and Medium Enterprises (SMEs) contribute more than onethird to the country's gross domestic product (GDP). Past studies revealed that access to finance and entrepreneurial characteristics are often known as predictors of SMEs performance. Nonetheless, access to finance is still one of the pressing problems faced by SMEs in Malaysia. Studies on this topic have not been extensively explored particularly in the FELDA scheme. Hence, this paper attempts to investigate how access to finance and entrepreneurship characteristics affect SMEs business performance in the FELDA scheme. This study employed a survey research design. Data were collected from a sample of 368 SMEs and analysed using the Structural Equation Modelling (SEM). This study found the insignificant effect of access to finance on business performance. There was no significant effect of innovativeness and proactiveness on business performance. Interestingly, risk-taking was directly related to SMEs business performance. Overall, findings imply that SMEs in the FELDA scheme have difficulties getting financial access, dare to take bold actions in business but they are lacking the propensity in introducing new business ideas and are not fast enough in taking advantage of new business opportunities. The paper recommends that government agencies should provide adequate business support and financial access to improve SMEs entrepreneurial capabilities and business performance.
\end{abstract}


DOI: 10.35631/IJEMP.413007.

This work is licensed under CC BY 4.0
Keywords:

Access To Finance, Entrepreneurial Characteristics, Performance, And SMEs.

\section{Introduction}

The research topic on Small and medium-sized enterprises (SME) development needs no introduction. This is mainly due to the contribution of SMEs towards the economic development of a country and also profound interest in understanding how SMEs can withstand economic challenges and digital disruption. With regards to the contribution of SMEs toward the economic development of a country, SMEs contributed more than half of the Gross Domestic Product (GDP) and provided nearly three quarter of the total employment in the Organization for Economic Corporation Development's (OECD) member countries (OECD, 2018). In ASEAN, SMEs contributed between 30 percent and 53 percent of the gross domestic product (GDP) and represented between 52 percent and 97 percent of employment. In the case of Malaysia, SMEs employed 7.3 million people and contributed 38.3 percent of the Malaysia Gross Domestic Product (GDP) which is about RM521.7 billion in 2019 (Department of Statistics Malaysia, 2020).

Studies on access to finance for SMEs have attracted considerable interest over the recent times. This is because the topic is still pertinent particularly after financial crisis. Financing is the "bloodline" of a business. Past studies have revealed that access to finance as one of the key determinants of SMEs business performance (Fardous Alom et al., 2016; Moha Asri \& Manan, 2010; Chittithaworn et al., 2011; Indarti \& Langenberg, 2004). With adequate capital, SMEs able to grow their business, expand their business operation domestically and internationally, increase their production output and innovation (OECD, 2006). In Malaysia, Bank Negara Malaysia (the Central Bank of Malaysia) has introduced a comprehensive financial blueprint to SMEs financing which focused on five main areas namely financial ecosystem infrastructure, financing and guarantees schemes, channel for information search, debt settlement and management, and financial awareness programmes. However, despite a good financial ecosystem introduced by Bank Negara Malaysia, access to finance remained as one of the SMEs problems (Abdul Saleh \& Worthington, 2013). The impact of lack of access to finance will result SMEs rely on internal funding, used outdated technology, spend less budget on promotion and innovation, and depend on intensive labour. According to OECD (2006) and Klonowski (2012), the problem of lack of financial access faced by SMEs is a prevailing phenomenon across the global. With regards to the reasons why entrepreneurs failed in their business venture, Datuk Dr Syed Ali Alattas, President of the Malay Chamber of Commerce Malaysia (DPMM) noted in the Restructuring of the Malay Economic and Financial Management Seminar that one of the reasons of entrepreneurs failure to expand their business was due to the difficulty in obtaining loans from financial institutions ("SME Corp Targets," 2017).

Previous studies have noted that access to finance and entrepreneurial characteristics are the main determinants of SMEs business performance. According to literature review, past studies on SMEs in Malaysia mainly concentrated on identifying the factors influencing SMEs business performance. However, limited studies focus on the inter-relationship between access to finance and entrepreneurial characteristics on SMEs business performance particularly in the FELDA scheme. In addition, studies concerning on how entrepreneurial characteristics 
(orientations) individually influence business performance have not yet been fully explored. Therefore, the aim of this study is to examine the effect of financial access and entrepreneurial characteristics on business performance among SMEs entrepreneurs in the FELDA scheme. Specifically, the objectives of this study are as presented below:

i. To examine the relationship between access to finance and business performance of SMEs in the FELDA scheme; and

ii. To examine the relationship between entrepreneurial characteristics and business performance of SMEs in the FELDA scheme.

The results of this study will present more evidence on the inter-relationship between access to finance and entrepreneurial characteristics on SMEs business performance in the FELDA scheme and will provide insights in designing the SMEs development programme.

\section{Literature Review}

\section{SMEs Development in the FELDA Scheme}

Past studies have documented the contribution of the SMEs sector to the Malaysian economy. According to Moha Asri and Hamid (2008) and Raja Rasiah (2013), among the factors contributing to the success of SMEs in Malaysia were due to policies and programmes introduced by the Malaysian government such as industrialization and New Economic Policy (NEP). It is noted that a lot of SMEs have successfully listed their company on the Bursa Malaysia such as Serba Dinamik Holdings Berhad. Under the National Entrepreneurship Policy (Dasar Keusahawanan Negara 2030 or DKN 2030), SMEs are expected to contribute 41 percent to total country GDP, employ 62 percent of total employment and account for 25 percent of total export by the year 2030 .

In connection with SMEs development in the FELDA scheme, FELDA has introduced a new FELDA New Business Model 2025. Under this new business model, FELDA is aiming to produce 1,000 successful entrepreneurs by the year 2025. This initiative is a continuation of FELDA Vision 2020 which was introduced by the former Prime Minister Dato' Sri Mohd Najib Tun Abdul Razak. FELDA was established on July 1, 1956 under the Land Development Ordinance of 1956. The main aim of FELDA establishment is to alleviate poverty through involvement in the agricultural based economy. FELDA has encouraged the settlers and the second FELDA generation to involve in various business activities apart from managing their estates. A review by Mohd Sauh, Moha Asri and Abdul Rahman (2019) have documented that SMEs in the FELDA scheme have played a pivotal role in the rural economic development in Malaysia. There are 23,036 SMEs involved in various business activities in the FELDA scheme and have recorded RM1.792 billion in sales revenue in 2016. The entrepreneurial development in the FELDA is coordinated by the Entrepreneur Development Department. The department has worked with various agencies and academic institutions to develop SME entrepreneurs in the FELDA scheme. Various programmes and scheme were introduced such as Tabung SIUF (Pinjaman Skim Insentif Usahawan FELDA) or FELDA Entrepreneur Incentive Scheme; SAWARI program similar to One District One Industry Programme (ODOI) in each FELDA scheme region; collaboration with various agencies and institutions such as MARA (Majlis Amanah Rakyat), Jabatan Perikanan Malaysia, SME Corp, TEKUN and commercial banks in providing training, financial assistance and technical assistance to SMEs in the FELDA scheme; and finally build modern business centres at strategic locations in FELDA scheme. Notwithstanding of the strong business supports by the FELDA and other government agencies, past studies have revealed that limited studies have been conducted on SMEs 
development in the FELDA scheme (Sedek et al., 2004). According to a study conducted by Khalid et al. (2005), the SMEs in the FELDA scheme are weak in the area of marketing, production and do not have adequate capital. With regards to financial assistance, FELDA has introduced Tabung SIUF loans to eligible entrepreneurs in the FELDA scheme. According to FELDA Annual Report 2016, from 2002 to 2015, FELDA has disbursed RM 69.7 million in the form of loans to 4,875 SMEs entrepreneurs in FELDA scheme. On 15 May, 2014; FELDA has suspended the SIUF Fund scheme due to high outstanding default loans from the borrowers (FELDA Annual Report, 2016). According to a study conducted by Mohd Shaari (2014), SMEs entrepreneurs in the FELDA have difficulties in serving the Tabung SIUF loans due to various reasons. Therefore, it is timely to examine the effect of financial access and entrepreneurial characteristics on the performance of SMEs in the FELDA scheme.

\section{Small and Medium Enterprises (SMEs) and Business Performance}

With regards to SME definition, Ardic et al. (2011) revealed that there is little consensus on the SME definition. According to Harif, Osman, and Hoe (2010), SMEs are defined either based on the number of employees or based on monetary indicators. The National SME Development Council (NSDC) in Malaysia defined SMEs based on sales turnover and the number of full-time employees. According to the council, the threshold level for SMEs is having below 200 people employed (in manufacturing sector) and having less than 75 people for the service sector. In connection to SMEs business performance, there are two methods that are often used to measure business performance in the SMEs studies are either using the financial indicators or non-financial indicators (Acer, 1993; Paige \& Litrell, 2002; Rogoff et al., 2004; Hussain, Ismail, \& Shah, 2015). Previous studies have suggested to use the nonfinancial measures to measure SMEs business performance due to the difficulties of getting reliable financial data from small firms (Acer, 1993; Watson, 2007). This study used the nonfinancial measures to measure SMEs business performance in the FELDA scheme.

\section{Access to Finance}

Access to finance can be defined as "getting adequate, affordable financing over a suitable timescale" (Tagoe et al., 2005, p.336). Financial access is the bloodline of business, firms need adequate funding for business growth. Past studies revealed that there are two types of business funding which are internal financing and external financing. According to Rossi et al. (2016), internal funding are generated from retained-earning and firm used this funding to finance its business growth. A review of past studies revealed that internal funding is not sufficient and a firm need additional funding from the external institutions to finance the business growth (Cunat, 2007; Degry, de Goeij, \& Kappert, 2012). In addition, according to Moha Asri and Manan (2010), SMEs need adequate funding to finance new product development, invest on research and gain better knowledge and access usage of new technologies.

According to Kuntchev et al. (2013), there are 4 categories of firms in terms of access to financing which includes situations like: (i) a firm applied for the loan and was rejected; (ii) a firm applied for the loan and managed to get a partial loan; (iii) a firm applied for a loan and successfully obtained the loan; and (iv) a firm did not apply for the loan because it had enough capital. This study used the above-mentioned measurement to measure the financial access among SMEs in the FELDA scheme. Past studies have revealed inconsistent findings with regards to the effect of access to finance on business performance. For example, several studies have found that access to finance influenced business performance (Mambula, 2002; Attahir, 1998). Nonetheless, a study conducted by Indarti and Langaberg (2004) on SMEs in Indonesia found no evidence on the effect of capital access and government support on business Copyright (C) GLOBAL ACADEMIC EXCELLENCE (M) SDN BHD - All rights reserved 
performance. Hence, this study suggests that access to finance will have a direct effect on the performance. Based on the empirical evidence the following hypothesis is formulated.

$\mathrm{H} 1$ : Access to finance is positively related to SMEs business performance.

\section{Entrepreneur Characteristics}

The word entrepreneur comes from a French word "entreprendre" means to undertake; to launch; to begin something. According to previous studies, there are two approaches in investigating the effect entrepreneurial characteristics on business performance. The first approach is based on the individual traits and social factors such as personal background, demographic characteristics and life experiences and the second approach is based on entrepreneurial activities of a firm, which is also known as entrepreneurial orientation.

According to Rauch et al. (2009) and Wiklund and Shepherd (2005), entrepreneurial orientation is defined a firm's ability to innovate, take risk and pursue new or unattended markets. Entrepreneurial orientation comprised of innovativeness, proactiveness, risk taking, autonomy and competitive aggressiveness. Wiklund (1999) noted that most of the studies on SMEs entrepreneurial characteristics used three dimensional models which comprised of innovativeness, proactiveness and risk taking to measure entrepreneurial orientation. With regards to innovativeness, it is defined as the readiness to come up with novel idea and willing to challenge the process (Rauch et al., 2009). Proactiveness refers to the progressive approach of a company to take advantages on the opportunities exist in the existing market and new market earlier than other rivals (Rauch et al., 2009). Risk taking refers to the preparedness to enter in the risk business venture (Omisakin et al., 2016).

Past studies have revealed that there are two approaches to examine the effect of entrepreneurial characteristics (EO) on business performance. The first method is by using EO as a single construct and the second method is by using individual dimension of entrepreneurial orientation. According to Lumpkin and Dess (1996) and Wiklund and Shepherd (2005) revealed that not all entrepreneurial characteristics (orientation) dimensions had a direct effect on business performance. Each entrepreneurial orientation dimension can be measured independently. According to a review of past studies revealed that each entrepreneurial orientation dimension has a different effect on business performance. For example, a study conducted by Swierczek and Ha (2003) found that risk taking was not significant with business performance; however innovativeness and proactiveness hypotheses were supported. In another study conducted by Hughes and Morgan (2007) found no evidence on the effect of innovativeness and risk taking on performance. In this present study, entrepreneurial characteristics are measured based on individual dimensions using innovativeness, proactiveness and risk taking. This is in accordance with the review of previous studies that have suggested that entrepreneur characteristics (include innovativeness, proactiveness and risk taking) individually will have a direct effect on business performance. Consequently, based on the above evidence the following hypothesis is formulated.

$\mathrm{H} 2$ : Innovativeness is positively related to SMEs business performance.

H3: Proactiveness is positively related to SMEs business performance.

H4: Risk taking is positively related to SMEs business performance.

\section{Underlying Theories}

Two theories are used to explain the effect of financial access and entrepreneurial characteristics on SMEs business performance which are the Resource based view (RBV) and Agency theory. According to the Resource based view theory, a firm can achieve above Copyright $\odot$ GLOBAL ACADEMIC EXCELLENCE (M) SDN BHD - All rights reserved 
Volume 4 Issue 13 (March 2021) PP. 89-108 DOI: 10.35631/IJEMP.413007

average performance when a firm able to own resources and capabilities that are valuable, rare, inimitable, and non-substitutable (VRIN). According Barney (1991), a firm will be able to achieve sustainable competitive advantages over other firms when the firm possess the VRIN resources and capabilities. According to RBV theory, to achieve superior performance a firm must have VRIN tangible resources such as physical business infrastructure, adequate financing, technologies, skilled workers, and also intangible resources such as knowledge, skills and brand. Consequently, when a firm that has access to finance, high entrepreneurial orientation (characteristics) and sound track records with adequate government business support will have more organizational capabilities than its competitors and are expected to achieve superior performance.

With regards to Agency theory, this theory is used to explain the financing constrained phenomenon faced by the SMEs (Bhaird \& Lucey, 2008; Mahmood, 2000). Agency theory posits that a principal engaged an agent to carry out the duties under a contract (Jensen \& Meckling, 1976; Parker, 1984). An agent will perform its duties based on the mandates given by the principle. The principal agent conflicts arise in the SMEs financial access issue due to three reasons namely asymmetrical information, moral hazard and adverse selection. In the case of SMEs, SMEs entrepreneurs have difficulties to get the funding facilities due to unable to provide adequate information to the financial institution to support their loan application, some SMEs used the financial facilities for non-business activities and financial institutions unable to identify the genuine applicants.

Hence, based on the above literature review discussion, the study proposed a conceptual framework of this study as presented in Figure 1. This study proposed that access to finance and entrepreneurial characteristics would influence SMEs business performance. In this paper, the discussion of the findings will focus on four hypotheses as presented in the above discussion.

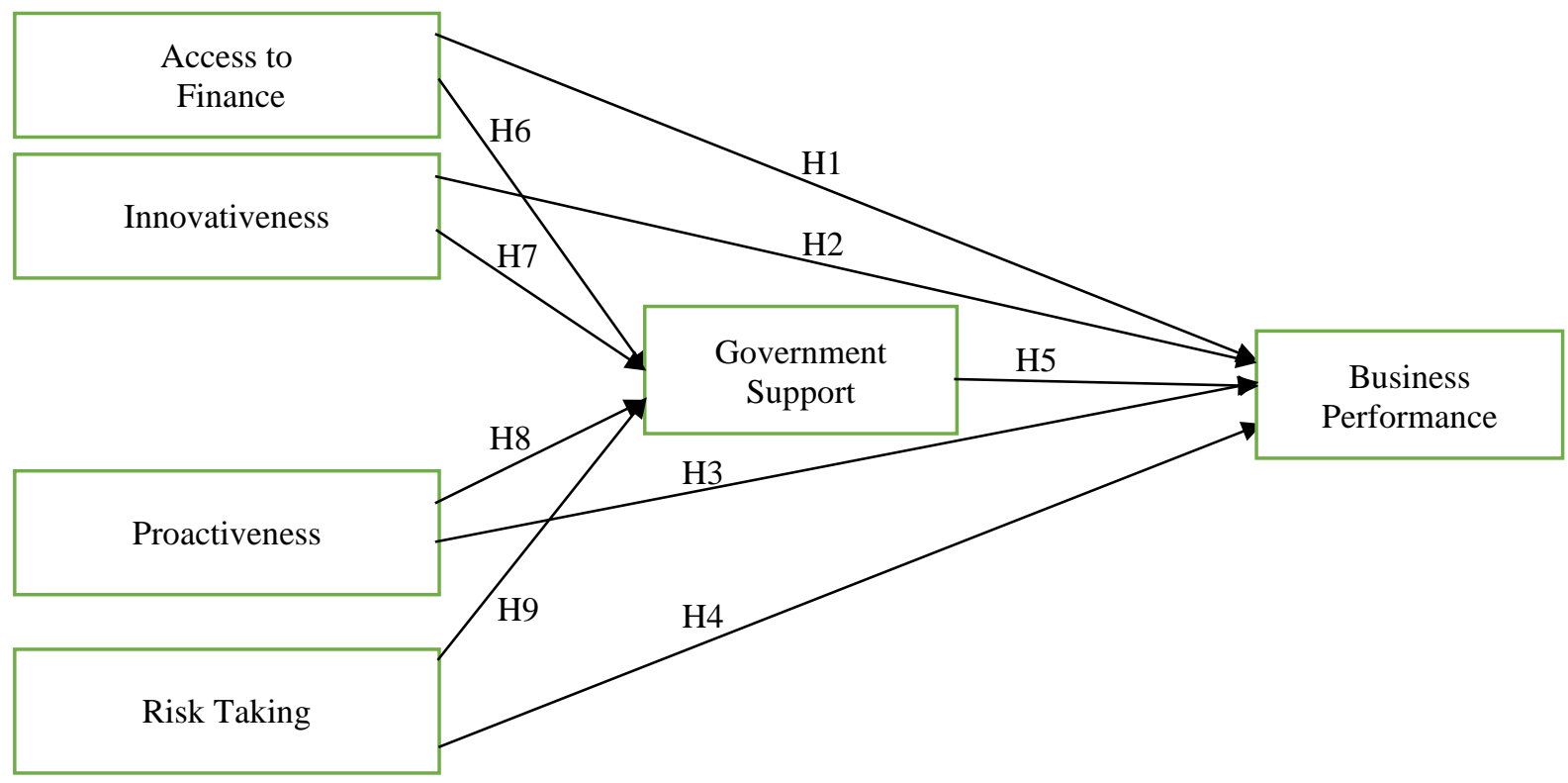

Figure 1: Conceptual Framework of Research 


\section{Methods}

\section{Research Design}

In finding the answer for the research questions of this study, this study used a deductive approach and employed the survey research as a research strategy. This present study is a crosssectional study. The population of this study comprised of 8,666 SME business entrepreneurs in the FELDA scheme located in Pahang. The unit of analysis of the present study is the individual (owner) or managers of the SMEs in the FELDA scheme in Pahang. The FELDA scheme in Pahang was divided into three regions, namely, Mempaga, Kuantan and Jengka. Based on Krejcie and Morgan (1970) sample size determination table, the suggested number of sample size is 368 respondents. The sample size was drawn from the entrepreneurs list provided by the FELDA Entrepreneur Development Department (Jabatan Pembangunan Usahawan FELDA). This study employed stratified sampling. Stratified sampling is suitable for this study because it is the most efficient among all the probability sampling as all the groups have equal chances to be selected and the comparison between groups is made possible (Sekaran \& Bougie, 2013).

\section{Instrument}

This study employed a survey questionnaire as the data collection method. The main constructs of this study included financial access, entrepreneur characteristics (orientation), government business support and SME business performance that were measured on the interval scale of 1 to 10, 1 is assigned as strongly disagree and 10 is assigned as strongly agree. The items of the variables in the questionnaires were adopted, adapted and modified from past studies.

The questionnaire in this study is divided into four sections. Section A relates to the respondents' background or entrepreneur characteristics; Section B contains to the background of the business or firm characteristics; Section C contains the main variables in this study which include financial access, entrepreneurial characteristics (orientation), government business support and business performance; and Section D presents questions about information on business operations.

The original questionnaire was developed in English. In light of the majority of the SMEs respondents in the FELDA scheme cannot read and write in English, the questionnaire was then translated into Bahasa Malaysia. The researcher pre-test the questionnaire to check the content validity, criterion validity and face validity of the instrument.

\section{Participants and Data Collection}

A field study was conducted at 114 FELDA schemes in Pahang. In total, 420 questionnaires were administered at the FELDA Scheme in Pahang region. Of the 420 questionnaires, 390 questionnaires were returned. 22 questionnaires were incomplete, and 368 questionnaires were analysed for a final analysis using SPSS version 21.

In term of demography profile of the respondents, out of the 368 respondents, 81.0 percent (298) of the respondents were owners and the other 19.0 percent (70) of the respondents were managers. The descriptive data indicates that most of the respondents were owners of their firms. With respect to the age profile, 13.3 percent (49) of the respondents were between 20 and 29 years old, 35.6 percent (131) were between 30 and 39 years old, 25.8 percent (95) were from the age of 40 to 49 years old, 16.0 percent (59) were between 50 and 59 years old and the rest 9.2 percent (34) of the respondents were 60 years old and above. The findings show that 
48.9 percent of SME entrepreneurs were below 40 years old and 51.1 percent were above 40 years old. This data reveals that young entrepreneurs are actively participating in business at the FELDA scheme.

In terms of the company information of the respondents, 90.2 percent (332) were sole proprietorships, 4.9 percent (18) were partnerships and the remaining 4.9 percent (18) were private limited companies. In addition, in terms of the type of business, 53 percent (195) were in service business, 6 percent (22) were in livestock business, 9.0 percent (33) were in manufacturing, 0.3 percent (1) was in craft works, 2.2 percent (8) were in agriculture, 0.5 percent (2) were in aquaculture and the rest (107) constituted 29.1 percent were in trading business. The findings revealed that half of the entrepreneurs ventured into the services business, followed by trading business and other businesses.

\section{Data Analysis}

\section{Exploratory Factor Analysis (EFA)}

Having performing descriptive data analysis, the second stage was conducting Exploratory Factor Analysis (EFA), confirmatory factor analysis (CFA) and structural equation modelling (SEM) that will be discussed in the next subsection. The present study used the developed questionnaire to collect data from entrepreneurs in the FELDA scheme in Pahang, the data collected were bound to exploratory factor analysis using Principal Component Analysis (PCA) based on varimax rotation. Particularly, EFA was done in order to ascertain whether observed variables were loaded together as expected, whether they were adequately correlated, met the reliability and validity criteria, and reduced data to a manageable size.

As a matter of common practice, several analysis are required to be conducted before embarking on exploratory factor analysis. Some of these analysis are Bartlett's test of sphericity, which is a measure of sample adequacy, and Kaiser-Meyer-Olkin (KMO), which is the test for null hypothesis that the correlation matrix has an identity matrix. These tests are performed to assess the appropriateness of factor analysis for the collected data (Kaiser, 1974). Accordingly, the results show an adequate value of KMO to be 0.857 , while Bartlett's test of sphericity is statistically significant (Chi-square is $7138.928, \alpha=0.000$ ). In addition, none of the matrix diagonal anti-image values was less than 0.500, indicating that there is no issues of multi-collinearity. Similarly, the communalities, which measures the amount of variance shared by the variables, are not highly compromised. The average communality is greater than 0.6 , and most of them are close to the acceptable benchmark of 0.7 as identified by Kaiser (1974). After checking the data suitability, the EFA was performed for this study. Having carried out EFA, the six-factors were extracted and explained an accumulated variance of approximately 68 percent with eigenvalue greater than one after rotation $(18.806,13.450$, $11.022,9.254,8.159$, and 7.383). Moreover, the reliability tests performed in accordance with the extracted factors are also presented in Table 1 below. This test was conducted for each factor using Cronbach's $\alpha$ coefficient. As presented in the table, the Cronbach's $\alpha$ coefficients for these factors are all above 0.7 as recommended by various statistical researchers, such as Hair et al. (2014), with the exception of risk taking which is 0.580 (access to finance $=0.872$, innovation $=0.873$, pro-activeness $=0.792$, risk taking $=0.580$, government supports $=0.717$, and business performance $=0.882$ ). In this study, reliability was represented by using the Cronbach alpha coefficient of which the value of 0.7 or higher indicate acceptable internal consistency. With respect to the risk taking, which is less than the 0.7 , the two items variable was retained because of its significant role in this study given the context of the study. As 
suggested by Schmitt (1996), variable with low value of alpha can still prove useful in some circumstances as in this study.

Consequently, these findings indicate that the data collected are suitable for conducting EFA. Moving on to the percentage trace, the first factor explains 18.81 percent of the total variance; the second factor explains 13.45 percent of the total variance; the third factor explains 11.02 percent of the total variance; the fourth factor explains 9.25 percent of the total variance; the fifth factor explains 8.16 percent of the total variance, and the sixth factor explains 7.38 percent of the total variance.

Table 1: Reliability Statistics

\begin{tabular}{llcc}
\hline S/N & Variable & Number of Item & Cronbach's Alpha \\
\hline 1 & Access to finance & 4 & 0.872 \\
2 & Innovativeness & 4 & 0.873 \\
3 & Pro-activeness & 4 & 0.792 \\
4 & Risk taking & 2 & 0.580 \\
5 & Government supports & 6 & 0.717 \\
6 & Business performance & 7 & 0.882 \\
\hline
\end{tabular}

Based on the six generated factors with significant factor loading, suitable meaning was assigned to each factor using the questionnaire developed for data collection, and Hair et al.'s (2014) recommendation were taken into account that the item with higher loading should have a reasonable influence on the name assigned to such factor. As presented in Table 2, the factor loadings for each factor are presented. In fact, the table illustrates a clean pattern with high loadings within the factors which confirms convergent and discriminant validity, without cross loading between the factors. Since all the factor loadings are above 0.40, which is the acceptable benchmark, the factors have demonstrated sufficient convergent validity for the study's sample size of 368 . More so, there were no issues of discriminant validity because of the correlation matrix (too large to show here) that demonstrates sufficient correlation between variables, and with no correlations above 0.700 .

Table 2: Exploratory Factor Analysis

\begin{tabular}{|c|c|c|c|c|c|c|}
\hline \multicolumn{7}{|c|}{ Rotated Component Matrix } \\
\hline & 1 & 2 & 3 & 4 & 5 & 6 \\
\hline$\overline{\text { AccessF4 }}$ & .974 & & & & & \\
\hline AccessF3 & .973 & & & & & \\
\hline AccessF1 & .863 & & & & & \\
\hline AccessF2 & .551 & & & & & \\
\hline Innovativeness 2 & & .902 & & & & \\
\hline Innovativeness 1 & & .869 & & & & \\
\hline Innovativeness 4 & & .862 & & & & \\
\hline Innovativeness 3 & & .782 & & & & \\
\hline Proactiveness3 & & & .834 & & & \\
\hline Proactiveness1 & & & .830 & & & \\
\hline Proactiveness2 & & & .776 & & & \\
\hline Proactiveness4 & & & .706 & & & \\
\hline RiskTaking2 & & & & .842 & & \\
\hline RiskTaking1 & & & & .842 & & \\
\hline
\end{tabular}


Volume 4 Issue 13 (March 2021) PP. 89-108 DOI: 10.35631/IJEMP.413007

GovernmentS4

GovernmentS5

GovernmentS6

GovernmentS3

GovernmentS1

GovernmentS2

BusinessP1

BusinessP2

BusinessP3

BusinessP4

BusinessP7

BusinessP6

BusinessP5
.825

.818

.785

.607

.516

.457

Extraction Method: Principal Component Analysis.

.866

.851

.843

.808

.776

.585

.584

\section{Confirmatory Factor Analysis}

Having reduced variables to manageable sizes, the researcher observed that the variables are loaded together as expected and are adequately correlated and met the reliability and convergence validity criteria through exploratory factor analysis. Next, the present section continues on the confirmatory factor analysis using structural equation modelling software Analysis of Moment Structure (AMOS). While performing structural equation modelling, the first stage is to assess and develop a measurement model. This is to specify how well the measured variables have formed together to denote the latent variables - that is, constructs. To assess the measurement model, it is incumbent upon the researcher to define the labels used for the constructs and how many items were designed for the sake of the present study. Using the exploratory factor analysis' factor loading matrix discussed above, the study's measurement model contains six constructs with a total of 27 items as shown in Table 2. Moreover, the items of the six constructs have significant loadings that are greater than 0.4. In addition, modification indices were consulted to improve the model; however, no further improvements could benefit the model beyond its present condition after covariate and deleted some items. In this case, error terms 5 and 6, 7 and 8,11 and 12, and 13 and 14 were covariates; and items on business performance 6 (BusinessP6), government supports 1 (GovernmentS1), government supports 2 (GovernmentS2), and government supports 3 (GovernmentS3) were deleted for the purpose of model improvement. Therefore, the researcher was left with 23 items after deleting the above items and these items were eventually used to perform confirmatory factor analysis for this study. Based on this, Table 3 below shows that the goodness of fit for the study's measurement model is sufficient (Normed Chi-square $=2.255$, Comparative Fit Index $(\mathrm{CFI})=0.958$, Incremental Fit Index (IFI) $=0.959$, Goodness of Fit Index $(\mathrm{GFI})=0.901$, Root Mean Square Error of Approximation (RMSEA) $=0.058$, PClose $=0.024$, Standardized Root-Mean-Square Residual $($ SRMR $)=0.058)$. In accordance with Hair et al. $(2014)$, three or four model fit indices are required to justify that the data fits the model well; as such, the measurement model of this study has now met the required level of model fit.

Based on this, factor scores, through data imputation, were generated and used in testing the relationships between the independent and dependent variables which are discussed in the subsequent section. 
Table 3: Goodness-of-Fit Statistics for the Measurement Model

Volume 4 Issue 13 (March 2021) PP. 89-108

DOI: 10.35631/IJEMP.413007

\begin{tabular}{lccc}
\hline \multicolumn{1}{c}{ Measure } & Estimate & Threshold & Interpretation \\
\hline CMIN & 475.787 & -- & -- \\
DF & 211 & -- & -- \\
CMIN/DF & 2.255 & Between 1 and 3 & Excellent \\
CFI & 0.958 & $>0.90$ & Excellent \\
IFI & 0.959 & $>0.90$ & Excellent \\
RMSEA & 0.058 & $<0.06$ & Excellent \\
PClose & 0.024 & $>0.05$ & Acceptable \\
SRMR & 0.058 & $<0.08$ & Excellent \\
\hline
\end{tabular}

\section{Assessment of Validity in the First-Order Confirmatory Factor Analysis}

After establishing that the data fits the model well as discussed above, the next step is the assessment of validity of the results; by validity, the researcher specifically refers to the convergent validity and discriminant validity. In testing convergent validity, which is the degree to which the theoretically-related constructs are indeed related, the researcher estimated the Average Variance Extracted (AVE). As shown in Table 5, AVE for this study are ranged between 0.428 and 0.704; this shows that some of the AVE values are below the suggested 0.50 level, according to Fornell and Larcker (1981). However, this is not an issue since the estimated parameter of this construct is higher in value and t-values are statistically significant as presented in Table 4 (Zabker, 2000).

Table 4: Regression Weights

\begin{tabular}{lrrrr}
\hline & Estimate & S.E. & C.R. & P \\
\hline RISKTAKING & .978 & .116 & 8.432 & $* * *$ \\
INNOVATIVENESS & 1.180 & .051 & 23.267 & $* * *$ \\
PROACTIVENESS & .853 & .064 & 13.236 & $* * *$ \\
ACCESSF & .390 & .047 & 8.375 & $* * *$ \\
BUSINESSP & .988 & .035 & 28.578 & $* * *$ \\
INNOVATIVENESS & .856 & .067 & 12.693 & $* * *$ \\
INNOVATIVENESS & 1.031 & .061 & 16.977 & $* * *$ \\
PROACTIVENESS & .896 & .065 & 13.765 & $* * *$ \\
PROACTIVENESS & .799 & .070 & 11.492 & $* * *$ \\
ACCESSF & 1.071 & .043 & 25.077 & $* * *$ \\
ACCESSF & 1.101 & .044 & 25.224 & $* * *$ \\
GOVERNMENTS & 1.439 & .091 & 15.789 & $* * *$ \\
GOVERNMENTS & 1.474 & .093 & 15.774 & $* * *$ \\
BUSINESSP & 1.082 & .060 & 18.134 & $* * *$ \\
BUSINESSP & 1.117 & .066 & 16.959 & $* * *$ \\
BUSINESSP & .478 & .057 & 8.358 & $* * *$ \\
BUSINESSP & .927 & .065 & 14.357 & $* * *$ \\
\hline
\end{tabular}

Concerning the discriminant or divergent validity, which is used to confirm whether the measurements that are not related are actually unrelated, the researcher compared the square root of the AVE on the diagonal, as shown in Table 5 below, to inter-factor correlations. 
Although a thorough scrutiny of Table 5 reveals that some of the values of Mean Shared Variance (MSVs) are higher than the value of Average Variance Extracted (AVE), it is not an issue since the parameter estimate of this construct is higher in value and the t-values are statistically significant as shown in Table 4 (Zabker, 2000).

Meanwhile, the researcher also computed Composite Reliability (CR) for each construct in addition to the Cronbach's $\alpha$ coefficient presented in Table 1. As shown, the value of CR are above the minimum threshold of 0.70 in most cases (Hair et al., 2014).

The findings show that the researcher's constructs are reliable and they have authenticated the Cronbach's $\alpha$ coefficient reported in Table 1. For more details, the discussions so far on validity and reliability using the Average Variance Extracted (AVE), Mean Shared Variance (MSVs), and Construct Reliability (CR) are summarised in Table 5. 
Volume 4 Issue 13 (March 2021) PP. 89-108 DOI: 10.35631/IJEMP.413007

Table 5: Model Validity Measures

\begin{tabular}{|c|c|c|c|c|c|c|c|c|c|c|}
\hline & $\mathbf{C R}$ & AVE & MSV & ASV & BUSINESS & RISKTAKING & INNOVATION & PROACTIVE & ACCESS & GOVERNMENT \\
\hline BUSINESS & 0.882 & 0.563 & 0.335 & 0.234 & 0.750 & & & & & \\
\hline RISKTAKING & 0.597 & 0.428 & 0.612 & 0.311 & 0.552 & 0.654 & & & & \\
\hline INNOVATION & 0.871 & 0.633 & 0.778 & 0.339 & 0.569 & 0.667 & 0.796 & & & \\
\hline PROACTIVE & 0.782 & 0.476 & 0.778 & 0.375 & 0.579 & 0.782 & 0.882 & 0.690 & & \\
\hline ACCESS & 0.899 & 0.704 & 0.067 & 0.048 & 0.258 & 0.249 & 0.258 & 0.196 & 0.839 & \\
\hline GOVERNMENT & 0.823 & 0.585 & 0.142 & 0.094 & 0.377 & 0.360 & 0.282 & 0.331 & 0.094 & 0.765 \\
\hline
\end{tabular}

Note: BUSINESS =Business Supports, RISKTAKING =Risk Taking, INNOVATION =Innovativeness, PROACTIVE =Pro-activeness, ACCESS =Access to Finance, and GOVERNMENT =Government. 
In addition, the regression weights in Table 4 also confirm that the measurements are indeed valid and further analyses can be performed on them. At the end, Figure 2 represents the path diagram for the Confirmatory Factor Analysis (CFA).

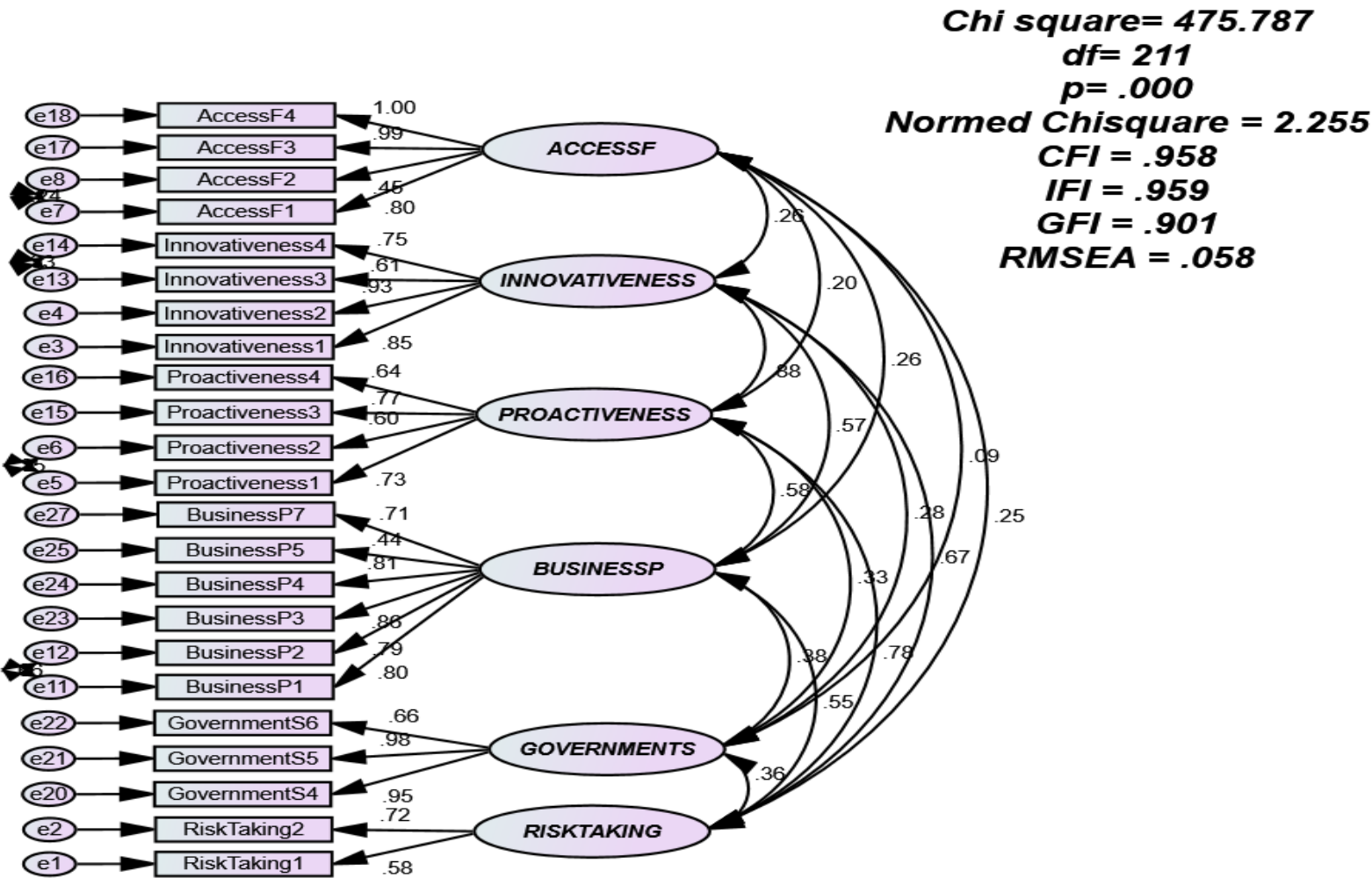

Figure 2: Measurement Model

\section{Results}

\section{Hypotheses Testing of the Research Model}

Having fulfilled the structural equation modelling assumptions, the researchers proceeded with testing the structural relationship between the dependent variable and independent variables. In this case, the influence of access to finance and business performance, innovativeness and business performance, pro-activeness and business performance, and risk taking and business performance were individually tested in order to reveal the variables that contribute to the performance of Small and Medium Enterprises (SMEs) in the FELDA scheme in Pahang. The findings of this analysis are shown below in the structural path diagram - Figure 2.

As mentioned previously, the six constructs with 23 items were used in the confirmatory factor analysis presented earlier - access to finance (AccessF1, AccessF2, AccessF3, and AccessF4), innovativeness (innovativeness1, innovativeness2, innovativeness3, and innovativeness4), pro-activeness (Proactiveness1, Proactiveness2, Proactiveness3, and Proactiveness4), risk taking (RiskTaking1 and RiskTaking2), government supports (GovernmentS4, GovernmentS5, and GovernmentS6), and business performance (BusinessP1, BusinessP2, BusinessP3, BusinessP4, BusinessP5, and BusinessP7) - are used in building the relationship between the endogenous and the exogenous variables. As shown and discussed earlier, the model fit indices obtained for the structural modelling are (Chi-square $=2.255$, Comparative 
Volume 4 Issue 13 (March 2021) PP. 89-108 DOI: 10.35631/IJEMP.413007

Fit Index $(\mathrm{CFI})=0.958$, Incremental Fit Index $(\mathrm{IFI})=0.959$, Goodness of Fit Index (GFI) $=0.901$, Root Mean Square Error of Approximation $($ RMSEA) $=0.058$, PClose $=0.024$, Standardized Root-Mean-Square Residual $($ SRMR $)=0.058)$, indicating that the model has met the acceptable level of model fit as recommended by Hair et al. (2014). As such, the hypothesized relationships are therefore discussed below.

Turning to the direct effects (in Figure 3 ) between the independent and the dependent variables: access to finance and business performance, innovativeness and business performance, proactiveness and business performance, and risk taking and business performance; the findings of the analyses performed in this regard are reported in Table 6.

Table 6: Regression Weights

\begin{tabular}{lllrrrc}
\hline & & & Estimate & S.E. & C.R. & P \\
\hline BUSINESSP & $<---$ & ACCESSF & .021 & .012 & 1.857 & .063 \\
BUSINESSP & $<---$ & PROACTIVENESS & .005 & .168 & .028 & .978 \\
BUSINESSP & $<---$ & INNOVATIVENESS & .215 & .117 & 1.841 & .066 \\
BUSINESSP & $<---$ & RISKTAKING & .487 & .104 & 4.706 & $* * *$ \\
\hline
\end{tabular}

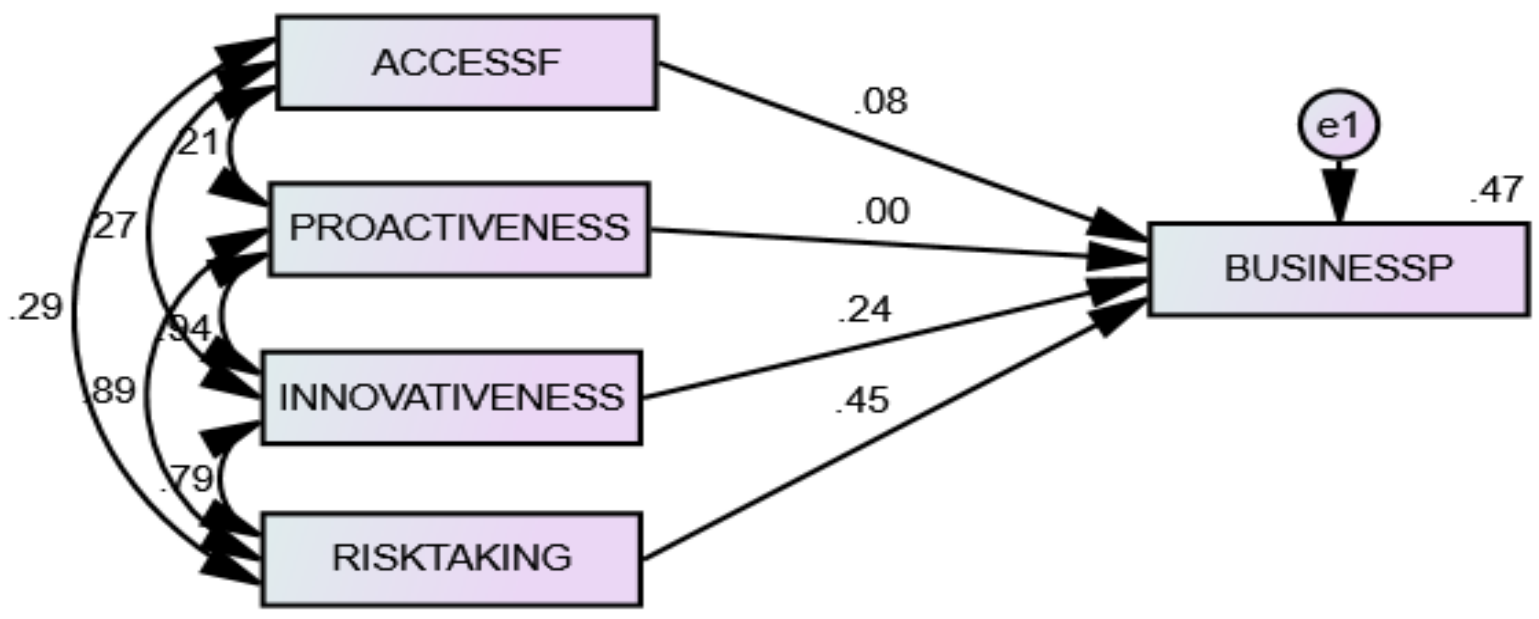

Figure 3: Structural Model

Specifically speaking, access to finance has a positive and insignificant influence on business performance $(\beta=0.021, p>0.05)$; pro-activeness has a positive and insignificant influence on business performance $(\beta=0.005, p>0.05)$; innovativeness has a positive and insignificant influence on business performance $(\beta=0.215, p>0.05)$; whereas, risk taking has a positive and significant influence on business performance $(\beta=0.487, p<0.001)$. These findings are shown in the Table 6.

Overall, all these variables (the effects of access to finance and business performance, innovativeness and business performance, pro-activeness and business performance, and risk taking and business performance) explain the 47 percent of the total variations in performance of SMEs in the FELDA scheme in Pahang. In terms of individual contribution based on the standardized regression weight, risk taking is the highest with 45 percent contribution to the business performance. This is followed by innovativeness with 23.6 percent contribution to the Copyright $\odot$ GLOBAL ACADEMIC EXCELLENCE (M) SDN BHD - All rights reserved 
business performance, access to finance with 7.8 percent contribution to business performance, and pro-activeness with 0.05 percent contribution to business performance.

\section{Discussion}

\section{Discussion on the First Objective}

This study examines the effect of access to finance on SMEs business performance in the FELDA scheme. Based on the analyses carried out, the study found that access to finance does not have any significant effect on the SMEs' business performance in the FELDA scheme in Pahang. The result reveals that SMEs in the FELDA scheme have limited access to finance. The result of the present study is opposed from the results by other researchers (Chittithaworn et al., 2011; Fatoki, 2011; Jasra et al., 2011; Ahmad et al., 2012; Machirori et al., 2012; Olugbenga, 2012; Mbuqua, 2013; Nabintu, 2013; Ofoeqbu, 2013; Kinyua, 2014; Ojokuku, 2014) who asserted that the access to finance has a significant effect on business performance. In consonance with a study by Moha Asri and Manan (2011) denoted that large firms gain more financial access as opposed to SMEs due to three reasons, namely, information asymmetry, adverse selection and moral hazard. With respect to information asymmetry, banks reluctant to grant loan to SMEs due to banks have limited information about SMEs' financial status as compare to large firms. Pertaining to the adverse selection problem, that is, banks unable to identify best-returned SME firms. Therefore, banks impose collateral and large firms would be able to comply with the requirement to minimize this problem. Concerning to the moral hazard, banks anticipate that SMEs may mismanage their financial funds. Hence, banks imposed higher covenants to SMEs. These are the factors that deprived SMEs from getting financial access.

\section{Discussion on the Second Objective}

This study also examines the effect of entrepreneurial characteristics on SMEs business performance in the FELDA scheme. Starting with innovativeness, the finding of this study found no evidence on the effect of innovativeness on SME business performance. This finding implies that EO dimension of innovativeness does not have any significant implication on the business performance of SMEs in the FELDA scheme. The finding of this study contradicts the findings of Hughes and Morgan (2007) and Swierczek and Ha (2003). The result of this study found that innovativeness is not directly related to business performance. The result suggests that the SMEs in the FELDA scheme lack the propensity to introduce new ideas or processes in their business.

Pertaining to proactiveness, the findings of this study show that there is no significant effect between proactiveness and SME business performance. This finding implies that proactiveness does not have any significant implication on the business performance of SMEs in the FELDA scheme. The finding of this study is inconsistent with the findings revealed by Hughes and Morgan (2007) and Swierczek and Ha (2003). The implication of this study's finding shows that proactiveness is not directly related to business performance. This indicates that SMEs in the FELDA scheme are reacting firms and are not acting fast enough to be the first company to seize market opportunities.

Interestingly on risk taking, the findings of this study revealed that there is a significant effect between risk-taking and SME business performance. This finding implies that risk-taking has a significant implication on the business performance of SMEs in the FELDA scheme. The finding of the present study is consistent with the finding revealed by Keh et al. (2007). The result of this study suggests that the SMEs in the FELDA scheme are willing to take bold 
actions and risks to venture into unexplored markets with an aim to generate more returns and enhance their firm's performance. Succinctly, the above results were consistent with the previous studies' findings which revealed that entrepreneurial characteristics (individual dimensions of entrepreneurial orientation) contribute differently to a firm's business performance.

\section{Conclusion}

Overall, the findings of the present study have demonstrated that SMEs in the FELDA scheme have difficulties to get financial access from the financial institutions. This study also found that SMEs in the FELDA scheme are lacking in terms of innovativeness and proactiveness capabilities. Engagingly, risk taking was directly related with SMEs business performance. The results of this study suggest that SMEs in the FELDA scheme are willing to take bold actions in business but they are lacking of propensity in introducing new business ideas and are not fast enough in taking advantage of new business opportunities. Given the importance of SMEs contribution in the FELDA scheme, this paper suggests that government agencies should provide adequate business support to improve financial accessibility among SMEs and provide the right trainings that can enhance their entrepreneurial capabilities particularly in the area of proactiveness and innovativeness which can improve the SMEs business performance in the FELDA scheme. With regards to the future research, this paper suggests a qualitative research should be conducted to gain more rich data and findings on SMEs business performance. Lastly, this paper also suggests that the similar study can be conducted to other regions of the FELDA scheme that enable FELDA to compare the findings between the regions in the FELDA scheme.

\section{References}

Ahmad, M., Ahmad, E., Kahut, M. B. H., \& Murtaza, G. (2012). New Determination of Factors Affecting the Growth of Small and Medium-Sized Enterprises in Pakistan. Interdisciplinary Journal of Contemporary Research in Business, 4(6), 513-530.

Attahir, Y. (1998). Small business development and survival in the South Pacific barriers and strategic responses. Journal of Entrepreneurship, 7(1), 49-65.

Acer, A. (1993). The impact of key internal factors on firm performance: An empirical study of small Turkish firms. Journal of Small Business Management. 86-92.

Ardic, O. P., Mylenko, N., \& Saltane, V. (2011). Small and Medium Enterprises A CrossCountry Analysis with a New Data Set. (Working Paper No. WPS 5538). World Bank. Retrieved from https://openknowledge.worldbank.org

Awang, A., Khalid, S. A., Yusof, A. A., Mohamed Kassim, K., Ismail, A., Ismail, M., Sheikh Zain, R., \& Madar, A. R. S. (2009). Entrepreneurial Orientation and Performance Relations of Malaysian Bumiputera SMEs: The Impact of Some Perceived Environmental Factors. International Journal of Business and Management, 4(9), 8496.

Barney, J. B. (1991). Resource-based theories of competitive advantage: A ten-year retrospective on the resource-based view. Journal of Management, 27(6), 643-650.

Bhaird, C. \& Lucy, B. (2008) Determinants of capital structure in Irish (SMEs). Small Business Economics, 35(3), 35-375.

Chittithaworn, C., Islam, M. A., Keawchana, T., \& Yusuf, D. H. M. (2011). Factors Affecting Business Success of Small \& Medium Enterprises (SMEs) in Thailand. Asian Social Science, 7(5), 180-190.

Cunat, V. (2007). Trade credit: Suppliers as debt collectors and insurance providers. Review Financial Studies, 20(2), 491-527. 
Degryse, H., De Goeij, P., \& Kappert, K. (2012). The impact of firm and industry characteristics on small firms' capital structure. Small Economics Business, 38(4), 431437.

Fairoz, F.M., Hirobumi, T., \& Tanaka, Y. (2010). Entrepreneurial orientation and business performance of Small and Medium Scale Enterprises of Hambantota District Sri Lanka. Journal of Asian Social Science. 6 (3), 34-46.

Fardous, A., Moha Asri, A., Abdul Rashid M. \& S.M. Ferdous A. (2016) Success factors of overall of micro enterprises in Malaysia: An empirical study. Journal of Global Entrepreneurship Research, 3-13.

Fatoki, O. \& Asah, F. (2011). The Impact of firm and entrepreneurial characteristics on access to debt finance by SMEs in King Williams' Town, South Africa. International Journal of Business and Management. 6, 170-179.

FELDA. (2017). Felda Annual Report 2016. Retrieved from www.felda.net.my.

Fornell, C., \& Larcker, D. F. (1981). Evaluating Structural Equation Models with Unobservable Variables and Measurement Error. Journal of Marketing Research, 18(1), 39.

Fowowe, B. (2017). Access to finance and firm performance: Evidence from African countries. Review of Development Finance, 7, 6-17.

Hair, J. F., Anderson, R.E., Tatham, R. L., \& Black, W. C. (1995). Multivariate Data Analysis with Readings (4th ed.). Englewood Cliffs, NJ: Prentice Hall.

Harif M., Osman H., \& Hoe C. (2010). Financial management practices: An in-depth study among the CEO of Small and Medium Enterprises. International Review of Business Research Papers, 6(6). 13-35.

Hughes, M., \& Morgan, R. E. (2007). Deconstructing the relationship between entrepreneurial orientation and business performance at the embryonic stage of firm growth. Industrial Marketing Management, 36(5), 651-661.

Hussain, J., Ismail K., \& Shah, F.A. (2015). The effect of market and entrepreneurial orientation and business performance: Study of Malaysian SMEs. City University Research Journal, 5(2), 203-218.

Indarti, N., \& Langenberg, M. (2004). Factors affecting business success among SMEs: Empirical evidences from Indonesia. Journal of Asia Entrepreneurship and Sustainability, 3(2), 1-14.

Jasra, J. M., Khan, M. A., Hunjra, A. I., Rehman, R. A. U., \& Azam, R. I. (2011). Determinants of business success of Small and Medium Enterprises. International Journal of Business and Social Science, 2(20), 274-280.

Jensen, M. C. \& Meckling, W. H. (1976). The theory of the firm: managerial behaviour, agency costs and ownership structure. Journal of Financial Economics, 3(4), 305-360.

Kaiser, H. F. (1974). An index of factorial simplicity. Psychometrika, 39(1), 31-36.

Keh, H. T., Nguyen, T. T. M., \& Ng, H. P. (2007). The effects of entrepreneurial orientation and marketing information on the performance of SMEs. Journal of Business Venturing, 22(4), 592-611.

Khalid, H., Abdullah, M. A., Md. Nor, N., Abdul Latif, A. \& Omar, I. (2005). Pembangunan Enterprais Kecil dan Sederhana (EKS) di Bandar Pusat Jengka, Pahang: Profil dan Prospek. Pulau Pinang: Universiti Sains Malaysia.

Kinyua, A. N. (2014). Factors Affecting the Performance of Small and Medium Enterprises in the Jua Kali Sector In Nakuru Town, Kenya. IOSR Journal of Business and Management 16(1), 80-93.

Klonowski, D. (2012). Liquidity gaps in financing the SME sector in an emerging market: evidence from Poland. International Journal of Emerging Markets, 7(3), 335-355. doi: https://doi.org/10.1108/17468801211237072 
Krejcie, R. V., \& Morgan D. W. (1970). Determining sample size for research activities. Education and Psychological Measurement Journal, 30, 607-610.

Kumar, A. (2005). Measuring financial access through users' surveys core concepts, question and indicators. (Paper prepared for the Joint World Bank/ DFID / Finmark Trust Technical Workshop).

Kuntchev, V., Ramalho, R., Rodriguez-Meza, J., \& Yang, J. S. (2013). What have we learned from the enterprise surveys regarding access to finance by SMEs? (World Bank Policy Research Working Paper No. 6670).

Lebans, M. \& Euske, K. (2006). A Conceptual and Operational Delineation of Performance. Business Performance Measurement. Cambridge: University Press.

Lumpkin, G. T. and Dess, G. G. (1996). Clarifying the entrepreneurial orientation construct and linking it to performance. The Academy of Management Review. 21(1), 135-172.

Machirori, T. L. (2012). The Impact of Networking on Access to Finance and Performance of SMEs in the Buffalo City Municipality, Eastern Cape, South Africa (Doctoral dissertation, University of Fort Hare).

Mambula, C. J. (2002). Perception of SME Growth Constraints in Nigeria. Journal of Small Business Management, 40(1), 58-65.

Mahmood, R. (2000). An empirical investigation of the lending decisions on small business by bank managers in Malaysia. (Unpublished doctoral dissertation). Glasgow Business School, University of Glasgow.

Matsuno, K., \& Mentzer, J. T. (2000). The effects of strategy type on the market orientationperformance relationship. Journal of Marketing, 64(4), 1-16.

Mbugua, J. K., Mbugua, S. N., Wangoi, M., Ogada, J. O., \& Kariuki, J. N. (2013). Factors Affecting the Growth of Micro and Small Enterprises: A Case of Tailoring and Dressmaking Enterprises in Eldoret. International Journal of Business \& Social Science, 4(5), 285-293.

Moha Asri, A., \& Ab. Manan, S. K. (2010). Adequacy of financial facilities for small-medium businesses: Empirical findings from Malaysia. International Review of Business Research Papers, 6(4), 535-548.

Mohd Sauh, S., Moha Asri A., \& Abdul Rahman R. (2019). Development of Small and Medium Enterprises (SMEs) in FELDA Scheme: Challenges and Policy Prospect. South East Asia Journal of Cotemporary Business Economics and Laws. 18(2), 1-10.

Mohd Shaari M.S., (2014). Assessing the factors influencing the repayment of SIUF Fund Scheme in FELDA Bukit Rokan and Bukit Rokan Utara. IIPM Working Paper: International Institute of Plantation Management.

Morgan, R. E., \& Strong, C. A. (2003). Product-market positioning and prospector strategy: An analysis of strategic patterns from the resource-based perspective. European Journal of Marketing, 37(10), 1409-1439.

Nabintu, N. (2013). Factors Affecting the Performance of Small and Micro Enterprises (SMEs) Traders at City Park Hawkers Market In Nairobi County, Kenya (Doctoral dissertation).

Ofoegbu, E. O., Akanbi, P. A., \& Joseph, A. I. (2013). Effects of Contextual Factors on the Performance of Small and Medium Scale Enterprises in Nigeria: A Case Study of Ilorin Metropolis. Journal of Advances in Management \& Applied Economics, 1, 95-114.

Ojokuku, R. M., Sajuyigbe, A. S., \& Ogunwoye, A. B. (2014). Human Resource Management Practices and Small Scale Business Performance: Evidence From Osun State, South Western Nigeria. Journal of Emerging Trends in Economics and Management Sciences, 5(7), 1-6. 
Olugbenga, A. A. (2012). Policy Support and Performance of Small and Medium Scale Enterprises in South-West Nigeria. European Journal of Business and Management, 4(9), 10-18.

Omisakin O.M, Nakhid, C., Littrell, R., \& Verbitsky, J. (2026). Entrepreneurial orientation among Migrants and Small and Medium Enterprises. Journal of Business Administration Research. 5(1).

OECD. (2006). New Approaches to SME and Entrepreneurship Financing-Broadening the Range of Instruments. Istanbul.

Paige, R. C., \& Litrell, M. A. (2002). Craft retailers' criteria for success and associated business strategies. Journal of Small Business Management, 4(4), 314-331.

Parker, R. H. (1984). Macmillan Dictionary of Accounting. London: Macmillan Press.

Rauch, A., Wiklund, J., Lumpkin, G. T., \& Frese, M. (2009). Entrepreneurial orientation and business performance: An assessment of past research and suggestions for the future. Entrepreneurship Theory and Practice, 33(3), 761-781.

Rogoff, E. G., Lee, M. S., \& Suh, D. C. (2004). Who done it? Attributions by entrepreneurs and experts of the factors that cause and impede small business success. Journal of Small Business Management, 42(4), 364-376.

Rossi, M., Lombardi, R., Siggiaand, D., \& Oliva, N. (2016). The impact of corporate characteristics on the financial decisions of companies: evidence on funding decisions by Italian. Journal of Innovation and Entrepreneurship, 5(2), 1-14.

Schmitt, N. (1996). Uses and abuses of coefficient alpha. Psychological Assessment, 8(4), 350353.

Sekaran, U. and Bougie, R. (2013). Research Methods for Business. John Wiley \& Sons Ltd., Chichester.

SME Corp targets 100,000 SMEs to use digital payment by year-end. (2017, March 2). Bernama.

SME Report (2020). 2019 Small and Medium Enterprises (SMEs) Performance. Department of Statistics Malaysia. https://www.dosm.gov.my

Swierczek, F. W., \& Ha, T. T. (2003). Entrepreneurial orientation, uncertainty avoidance and firm performance: an analysis of Thai and Vietnamese SMEs. The International Journal of Entrepreneurship and Innovation, 4(1), 46-58.

Tagoe, N., Nyarko, E., \& Anuwa-Amarh, E. (2005). Financial challenges facing urban SMEs under financial sector liberalization in Ghana. Journal of Small Business Management, 43(3), 331-343.

Watson, J. (2007). Modelling the relationship between networking and firm performance. Journal of Business Venturing, 22(6), 852-874.

Wiklund, J. (1999). The sustainability of the entrepreneurial orientation - Performance Relationship. Entrepreneurship Theory and Practice, 24(1), 37-48.

Wiklund, J., \& Shepherd, D. (2005). Entrepreneurial orientation and small business performance: A configurational approach. Journal of Business Venturing, 2(1), 71-91.

Yong O.K., \& Vineles, P. G. (2016). ASEAN Community: Integration and Development of SMEs. 202. Retrieved from https://www.rsis.edu.sg/wpcontent/uploads/2016/08/C)16202.pdf

Zabker, V. (2000). Some Methodological Issues with Structural Equation Model Application in Relationship Quality Context. New Approaches in Applied Statistics, 16, $211-$ 226. 